\title{
Response to
}

Citation for published version (APA):

Beuken, J. A., Verstegen, D. M. L., Dolmans, D., Van Kersbergen, L., Losfeld, X., Sopka, S., Vogt, L., \& Bouwmans, M. E. J. (2020). Response to: Overly optimistic picture of current state of cross-border patient care in 'Going the extra mile' by Beuken JA, Verstegen DML, Dolmans D, et al. BMJ Quality \& Safety, 29(12), 1048-1049. https://doi.org/10.1136/bmjqs-2020-011224

\section{Document status and date:}

Published: 01/12/2020

DOI:

10.1136/bmjqs-2020-011224

Document Version:

Publisher's PDF, also known as Version of record

\section{Document license:}

Taverne

\section{Please check the document version of this publication:}

- A submitted manuscript is the version of the article upon submission and before peer-review. There can be important differences between the submitted version and the official published version of record.

People interested in the research are advised to contact the author for the final version of the publication, or visit the DOI to the publisher's website.

- The final author version and the galley proof are versions of the publication after peer review.

- The final published version features the final layout of the paper including the volume, issue and page numbers.

Link to publication

\footnotetext{
General rights rights.

- You may freely distribute the URL identifying the publication in the public portal. please follow below link for the End User Agreement:

www.umlib.nl/taverne-license

Take down policy

If you believe that this document breaches copyright please contact us at:

repository@maastrichtuniversity.nl

providing details and we will investigate your claim.
}

Copyright and moral rights for the publications made accessible in the public portal are retained by the authors and/or other copyright owners and it is a condition of accessing publications that users recognise and abide by the legal requirements associated with these

- Users may download and print one copy of any publication from the public portal for the purpose of private study or research.

- You may not further distribute the material or use it for any profit-making activity or commercial gain

If the publication is distributed under the terms of Article $25 \mathrm{fa}$ of the Dutch Copyright Act, indicated by the "Taverne" license above, 
Response to: Overly optimistic picture of current state of crossborder patient care in 'Going the extra mile' by Beuken JA, Verstegen DML, Dolmans $\mathrm{D}$, et al

As authors, we were pleased to read the elaborate comments in the correspondence from Kringos et $a l^{1}$ regarding our study, 'Going the extra mile-cross-border patient handover in a European border region: qualitative study of healthcare professionals' perspectives'. ${ }^{2}$ We were happy to read that we succeeded in articulating the need for attention to professionals' role in cross-border healthcare, especially with regards to the identified challenges (information transfer, differences in task division and education, use of tools and protocols and cultural and language differences). Kringos and colleagues make some excellent points. We would like to elaborate on some of the comments, namely the argued overestimation of crossborder healthcare use, the limited attention for patients and the modesty of proposed actions.

\section{OVERESTIMATION OF CROSS- BORDER HEALTH CARE USE}

Of the overall European population, only a small proportion receives cross-border healthcare. This is, however, different in border regions. Our study was set in a region where three large hospitals are situated in three different countries within a radius of $25 \mathrm{~km}$. We purposefully selected three settings in this region, where collaboration was explicit. We agree that these settings might not be representative for Europe at large. However, we believe the growing emphasis on cross-border healthcare, and the need for efficient use of resources and expertise in border-regions ${ }^{3}$ will eventually lead to increases in cross-border care. Therefore, it is important to study current experiences and potential ways to improve crossborder care.

\section{PATIENT PERSPECTIVE}

We agree with the correspondents that our study does not focus on the burden that cross-border healthcare puts on patients. Some of our respondents did report on patient involvement in the decision to cross borders for healthcare, but this was not perceived as a main subject, nor a challenge, for cross-border healthcare. It is possible that our respondents, healthcare professionals, are not always aware of burdens typically experienced by patients, such as arranging prior authorisation or reimbursement afterwards.

Since we feel there should be more attention for patients in the complexity of cross-border healthcare, we are currently finalising a study that focuses solely on their unique perspective. Although we agree that citizens and patients should have the ability to initiate, and be involved in, cross-border healthcare, we warn for inappropriate amounts of responsibility that sometimes seems to be expected of these patients. We believe healthcare professionals' awareness of cross-border healthcare is an important facilitator for patient involvement.

\section{MODESTY OF PROPOSED ACTIONS}

We agree that there is a need to support cross-border care on a European level. Supportive directives and regulations, as formulated by the European Committee, are important facilitators to reach agreements between neighbouring countries and nuance differences in local policies. However, as articulated in special report number $07 / 2019,{ }^{4}$ these directives and regulations require translation from politics to clinical practice, and further elaboration on a local level to support both professionals and patients. What we have learnt from the interviews, is that a onesize-fits-all solution does not exist. In clinical practice, there are large differences between unplanned and planned cross-border care, and between specific settings (eg, depending on languages spoken, diversity in task-descriptions, or the presence of professionals with clinical experience in different countries). Therefore, we argue that getting together to discuss challenges and fitting strategies for improvement, is an important link in the chain of optimising crossborder healthcare. Interaction between policy and practice will certainly enrich these discussions and fortify the outcomes, and should definitely be part of future supportive efforts.

\section{Juliëtte A Beuken $\odot$, 1 \\ Daniëlle M L Verstegen, ${ }^{1}$ Diana Dolmans, ${ }^{1}$ \\ Laura Van Kersbergen, ${ }^{2}$ Xavier Losfeld, ${ }^{3}$ \\ Saša Sopka, ${ }^{2,4}$ Lina Vogt, ${ }^{2,4}$ \\ Mara E J Bouwmans $\oplus^{1}$ \\ ${ }^{1}$ Educational Research and Development / School of Health Professions Education, Faculty of Health, Medicine and Life Sciences, Maastricht University, Maastricht, The Netherlands \\ ${ }^{2}$ Interdisciplinary Training Center of Medical Education and Patient Safety, Medical Faculty, RWTH Aachen University, Aachen, Nordrhein- Westfalen, Germany \\ ${ }^{3}$ Level 1 Trauma Center, Emergency Department, \\ CHR Citadelle, Liege, Belgium \\ ${ }^{4}$ Department of Anesthesiology, Medical Faculty, University Hospital RWTH Aachen, Aachen, Germany}

\section{Correspondence to}

Ms Juliëtte A Beuken, School of Health Professions Education, Faculty of Health, Medicine and Life Sciences, Maastricht University, Maastricht, The Netherlands; j.beuken@maastrichtuniversity.nl

Twitter Juliëtte A Beuken @julietbeuken Contributors All (co)authors have made sufficient contributions to this letter.

Funding This study was funded by European Regional Development Fund (INTERREG V-A programme).

Competing interests None declared. Patient consent for publication Not required.

\section{Provenance and peer}

review Commissioned; internally peer reviewed.

(C) Author(s) (or their employer(s)) 2020. No commercial re-use. See rights and permissions. Published by BMJ. 
A) Check for updates

To cite Beuken JA, Verstegen DML, Dolmans D, et al. BMJ Qual Saf 2020;29:1048-1049.

Received 20 April 2020

Accepted 22 April 2020

Published Online First 12 May 2020

\section{Linked}

http://dx.doi.org/10.1136/bmjqs-2020-011146

- http://dx.doi.org/10.1136/bmjqs-2019-010509
BMJ Qual Saf 2020:29:1048-1049.

doi:10.1136/bmjqs-2020-011224

\section{ORCID iDs}

Juliëtte A Beuken http://orcid.org/00000002-5431-9418

Mara E J Bouwmans http://orcid.org/ 0000-0003-4930-5051

\section{REFERENCES}

1 Kringos DS, Jansen F, Jansen T. Overly optimistic picture of current state of cross-border patient care in 'Going the extra mile' study. BMJ Qual Saf 2020;29:1046-7.
2 Beuken JA, Verstegen DML, Dolmans D, et al. Going the extra mile - cross-border patient handover in a European border region: qualitative study of healthcare professionals' perspectives. BMJ Qual Saf 2020;29:980-7.

3 Glinos IA, Baeten R, Helble M, et al. A typology of Cross-border patient mobility. Health Place 2010;16:1145-55.

4 European Court of Auditors. Special report no 07/2019: EU actions for Crossborder healthcare: significant ambitions but improved management required 2019. 